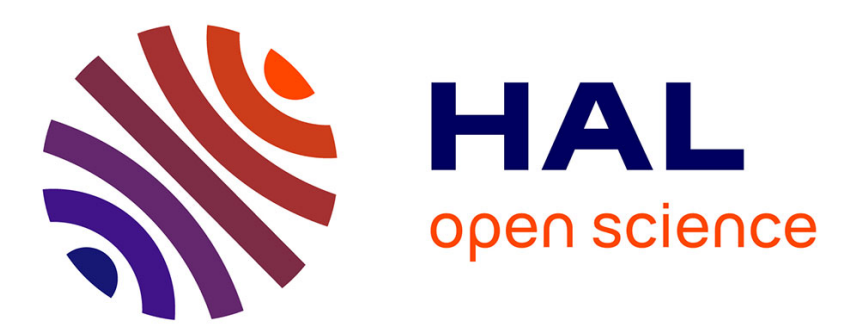

\title{
Expression of the Fgf6 gene is restricted to developing skeletal muscle in the mouse embryo
}

Odile Delapeyrière, Vincent Ollendorff, Jacqueline Planche, Marie-Odile Ott, Sandrine Pizette, François Coulier, Daniel Birnbaum

\section{- To cite this version:}

Odile Delapeyrière, Vincent Ollendorff, Jacqueline Planche, Marie-Odile Ott, Sandrine Pizette, et al. Expression of the Fgf6 gene is restricted to developing skeletal muscle in the mouse embryo. Development (Cambridge, England), 1993, 118 (2), pp.601-611. hal-02711884

\section{HAL Id: hal-02711884 \\ https://hal.inrae.fr/hal-02711884}

Submitted on 1 Jun 2020

HAL is a multi-disciplinary open access archive for the deposit and dissemination of scientific research documents, whether they are published or not. The documents may come from teaching and research institutions in France or abroad, or from public or private research centers.
L'archive ouverte pluridisciplinaire HAL, est destinée au dépôt et à la diffusion de documents scientifiques de niveau recherche, publiés ou non, émanant des établissements d'enseignement et de recherche français ou étrangers, des laboratoires publics ou privés. 


\title{
Expression of the Fgf6 gene is restricted to developing skeletal muscle in
}

\section{the mouse embryo}

\author{
Odile deLapeyrière ${ }^{1, *}$, Vincent Ollendorff ${ }^{1}$, Jacqueline Planche ${ }^{1}$, Marie Odile Ott $^{2}$, Sandrine Pizette ${ }^{1}$, \\ François Coulier ${ }^{1}$ and Daniel Birnbaum ${ }^{1}$ \\ ${ }^{1}$ Laboratoire d'Oncologie Moléculaire, U. 119 INSERM, 27 Bd. Leï Roure, 13009 Marseille, France \\ 2Département de Biologie Moléculaire, U.R.A. CNRS 1148, Institut Pasteur, 28 rue du Dr Roux, 75724 Paris Cedex 15, \\ France \\ *Author for correspondence
}

\section{SUMMARY}

Fgf6, a member of the Fibroblast Growth Factor (FGF) family, is developmentally regulated and its expression is highly restricted in the adult. To gain further insight into the role of $F g f 6$, we studied its expression during embryogenesis using RNA in situ hybridization. Fgf6 expression is restricted to developing skeletal muscle. Fgf6 transcripts are first detected in the somites at $\mathbf{9 . 5}$ days post-conceptus, and expression continues in developing skeletal muscles up to at least 16.5 days post-conceptus. $\mathrm{Fgfr} 4$ is a putative receptor for FGF6. Its pat- tern of expression during myogenesis overlaps that of Fgf6, but both genes are not expressed in exactly the same population of cells. In addition, recombinant FGF6 protein is able to repress the terminal differentiation of myoblasts in culture, providing additional support to the concept that FGF6 plays an important role in myogenesis.

Key words: fibroblast growth factor, FgfG, Fgfr4, mouse embryogenesis, myogenesis, skeletal muscle

\section{INTRODUCTION}

Intercellular communication plays a crucial role in embryonic development. Among a variety of signaling molecules are the fibroblast growth factors (FGF). They represent a family of structurally related mitogenic proteins (reviewed by Benharroch and Birnbaum, 1990; Goldfarb, 1990). In mammals, seven members of the FGF family are known at present, including aFGF/FGF1, bFGF/FGF2, INT2/FGF3, HST/K-FGF/FGF4, FGF5, FGF6 and KGF/FGF7. FGFs play important roles in various processes including development. They are involved in mesoderm induction and early embryonic pattern formation (Kimelman and Kirschner, 1987; Slack et al., 1987), as well as in later stages of embryonic development. FGF1 and FGF2 are broadly distributed in the embryo (Gonzalez et al., 1990; Fu et al., 1991) while the Fgf3, Fgf4 and Fgf5 genes are expressed during gastrulation and later in embryogenesis (Wilkinson et al., 1988, 1989; Haub and Goldfarb, 1991; Hébert et al., 1991; Niswander and Martin, 1992).

FGFs may be particularly important in some specific developmental processes such as myoblast differentiation. In agreement with this function, FGF1, FGF2, FGF4 and FGF5 have been shown to influence the differentiation of cultured myoblasts (Lathrop et al., 1985; Clegg et al., 1987; Seed and Hauschka, 1988; Olwin and Rapraeger, 1992; Goldfarb, personal communication). In addition, the corresponding genes are expressed during myogenesis (Gonza- lez et al., 1990; Fu et al., 1991; Haub and Goldfarb, 1991; Niswander and Martin, 1992).

The human FGF6 gene was cloned by low stringency hybridization to an FGF4 probe (Marics et al., 1989). We have previously reported the presence of murine Fgf6 transcripts in adult muscles and during embryogenesis (deLapeyrière et al., 1990). In order to define better the pattern of expression of $F g f 6$, we have now performed in situ hybridization on embryo sections. This has revealed a striking tissue-specific and spatially regulated pattern of expression during mouse development. Fgf6 RNA specifically accumulated in skeletal muscles.

Understanding the developmental role of the FGF6 growth factor also requires precise knowledge of the distribution of its cognate receptor. Four high affinity FGF receptor (FGFR) genes belonging to the the family of receptor-type tyrosine kinases have been cloned (Givol and Yayon, 1992, for review). Of the patterns of $F g f r$ expression that have been described (Orr-Urtreger et al., 1991; Peters et al., 1992; Stark et al., 1991; Yamaguchi et al., 1992), only that of Fgfr4 appears to overlap the distribution of Fgf6 transcripts. Furthermore, FGF6 is able to displace high affinity FGF1 binding to FGFR4 (Vainikka et al., 1992). Thus, FGFR4 may constitute a putative receptor for FGF6. With this in mind, we have performed a direct comparison of the expression of Fgf6 and Fgfr4 in muscle masses during embryogenesis.

Our data suggest that the Fgf6 gene may play an impor- 
tant role in muscle development. This role is discussed in regard to the in vitro capability of the FGF6 protein to repress the terminal differentiation of myoblast cells.

\section{MATERIALS AND METHODS}

\section{Probes}

Radiolabelled antisense probes were generated after linearization of plasmid DNA by restriction enzyme digestion and in vitro transcription, in the presence of ${ }^{35} \mathrm{~S}-$ labelled UTP, in standard reactions (Melton et al., 1984) using SP6, T3 or T7 RNA polymerase, depending upon the vector DNA template used. A 434 bp EcoRV fragment of the 'dream' plasmid containing the 3' untranslated part of Fgf6 cDNA (Ollendorff et al., 1992), was used as a probe for Fgf6. A plasmid containing $120 \mathrm{bp}$ of the 5' non-coding sequence of the murine $\alpha$-cardiac actin gene (Sassoon et al., 1988) and one containing $583 \mathrm{bp}$ of the $3^{\prime}$ untranslated region of the Fgfr4 cDNA (Stark et al., 1991), were used as probes for comparative studies along with Fgf6.

\section{Embryos}

Embryos were obtained from $\mathrm{C} 3 \mathrm{H} / \mathrm{He}$ inbred mice. Noon of the day on which the vaginal plug was detected was considered to be 0.5 day of gestation. Embryos were dissected from pregnant mice, fixed in $4 \%$ buffered paraformaldehyde at $4{ }^{\circ} \mathrm{C}$ and embedded in paraffin wax.

\section{In situ hybridization}

Serial microtome sections $(6 \mu \mathrm{m})$ were deparaffinized and hybridized with $50,000-75,000 \mathrm{cpm} / \mu 1{ }^{35} \mathrm{~S}$-labelled sense or antisense cRNA probes, according to the protocol described by Wilkinson et al. (1987), with minor modifications by Lyons et al. (1990). After the washes, the slides were dipped into Kodak NTB2 nuclear track emulsion diluted 1:1 and autoradiographed (for 45 weeks for Fgf6 and 1-2 weeks for the other probes). After photographic development, the slides were stained with toluidine blue and analyzed using both bright- and dark-field optics of a Zeiss Axiophot and a Nikon XA microscopes.

\section{Cells and culture conditions}

C2 mouse muscle cells (clone C2.7) were obtained from C. Pinset and D. Montarras (Institut Pasteur, Paris), and grown as myoblasts at subconfluent density, in a medium made of 50\% MCDB 202 $50 \%$ Dulbecco's modified medium (DME), supplemented with $20 \%$ FCS as described (Pinset et al., 1988). To test the activity of FGF6 and FGF2, cells were plated at 100-200 cells per $90 \mathrm{~mm}$ diameter culture dish in the presence of either 10 or $100 \mathrm{ng} / \mathrm{ml}$ recombinant protein with or without $0.1 \mu \mathrm{g} / \mathrm{ml}$ heparin (Sigma). Proteins were added every other day. After 8 days in culture, cells were induced to differentiate in DME containing $1 \% \mathrm{FCS}$, and 10 $\mu \mathrm{g} / \mathrm{ml}$ human insulin (Novo Nordisk Pharmaceutique). 48 or 72 hours later, cells were fixed. The number of differentiated colonies was estimated by morphological observation and by counting the number of troponin-T-positive colonies in a standard immunofluorescence procedure using a monoclonal antibody against troponin $\mathrm{T}$ (Amersham).

FGF2, produced by recombinant DNA technology, was a gift from H. Prats (Laboratoire d'Endocrinologie Expérimentale, Toulouse). Recombinant FGF6 was produced as previously described (Pizette et al., 1991).

\section{RNA isolation and northern analysis}

RNAs were extracted by the guanidine isothyocyanate-caesium chloride method from subconfluent $\mathrm{C} 2$ myoblasts and from $\mathrm{C} 2$ myotubes after 3 days in the differentiating medium. Equal amounts of total RNAs, as assessed by ethidium bromide stain- ing, were fractionated on $1 \%$ agarose $/ 10 \%$ formaldehyde gels and transferred onto nylon membranes (Nytran, Schleicher and Schuell). The same fragments as for in situ hybridization were used as probes after oligolabelling. The blot was first hybridized with an Fgfr4 fragment at $68^{\circ} \mathrm{C}$ for 20 hours, according to the method of Stewart and Walker (1989). The membrane was then rehybridized with an $\alpha$-cardiac actin probe to control for the myogenic differentiation.

\section{RESULTS}

\section{In situ analysis of the fetal expression of FGF6}

In order to localize $F g f 6$ expression during embryogenesis, sections of prefixed mouse embryos at various postimplantation stages of development were hybridized in situ to either antisense or sense $F g f 6$ probes. No signal above background was ever observed at any time using the sense probe (data not shown). No Fgf6 signal was detected at stages between 6.5 and 8.5 days post-conceptus (d.p.c.). Embryonic Fgf6 expression first occurred at 9.5 d.p.c. which is an early stage of differentiation of the myotomes (Ott and Buckingham, 1992) The Fgf6 signal appeared in the myotomal compartment of the somites (Fig. 1A-D). The dermatome and the sclerotome were not labelled in any of the embryos examined. At 11.5 d.p.c., $F g f 6$ transcripts were still abundant in the myotomes of the somites of the trunk (Fig. 1E) and in those near the hindlimb bud; the latter was negative (Fig. 1F). At 12.5 d.p.c., transcripts for Fgf6 were detected in the somites of the tail (data not shown). At this stage, Fgf6 mRNA was present in other regions as well, in particular in the developing skeletal muscles of the neck (Fig. 2A). However, Fgf6 transcripts were not detected in all the areas where $\alpha$-cardiac actin mRNA was present (Fig. $2 \mathrm{~A}, \mathrm{~B}$, and data not shown).

Fgf6 expression became more extensive between 13.5 and 14.5 days of gestation. Thorough examination of 13.5 and 14.5 d.p.c. embryos hybridized to the Fgf6 probe showed that Fgf6 expression occurred only in developing skeletal muscles (Fig. 2). This was confirmed by hybridization of parallel sections to the $\alpha$-cardiac actin probe. Fgf6 transcripts were detected in most skeletal musculature of the embryo: in the facial regions including the tongue, the jaw, the pharyngeal (Fig. 2C) and extrinsic ocular muscles (Fig. 2H,I); in the neck region (Fig. 2C); in the trunk region including the muscles surrounding the vertebral column, the ribs, the shoulder (Fig. 2C, D), the pelvis (not shown), the diaphragm and the thigh (Fig. 2J), and in the forelimbs (Fig. 2D) and hindlimbs (Fig. 2F). In limbs, there was a proximal-distal gradient of $F g f 6$ transcripts, whereas $\alpha$-cardiac actin expression was more distal (Fig. 2D,E), in keeping with an earlier onset of expression. No Fgf6 expression was observed in the heart at any stage, nor in smooth muscle.

The signal obtained with the Fgf6 probe differed from that of the $\alpha$-cardiac actin in two respects. First, a few muscle masses, positive for $\alpha$-cardiac actin, were negative for Fgf6 (Fig. 2A,B,D,E). It is possible, however, that these masses only express a low level of Fgf6 RNA, below the threshold of detection. Second, in many muscle masses, the $\alpha$-cardiac actin probe hybridized all over the block, whereas 

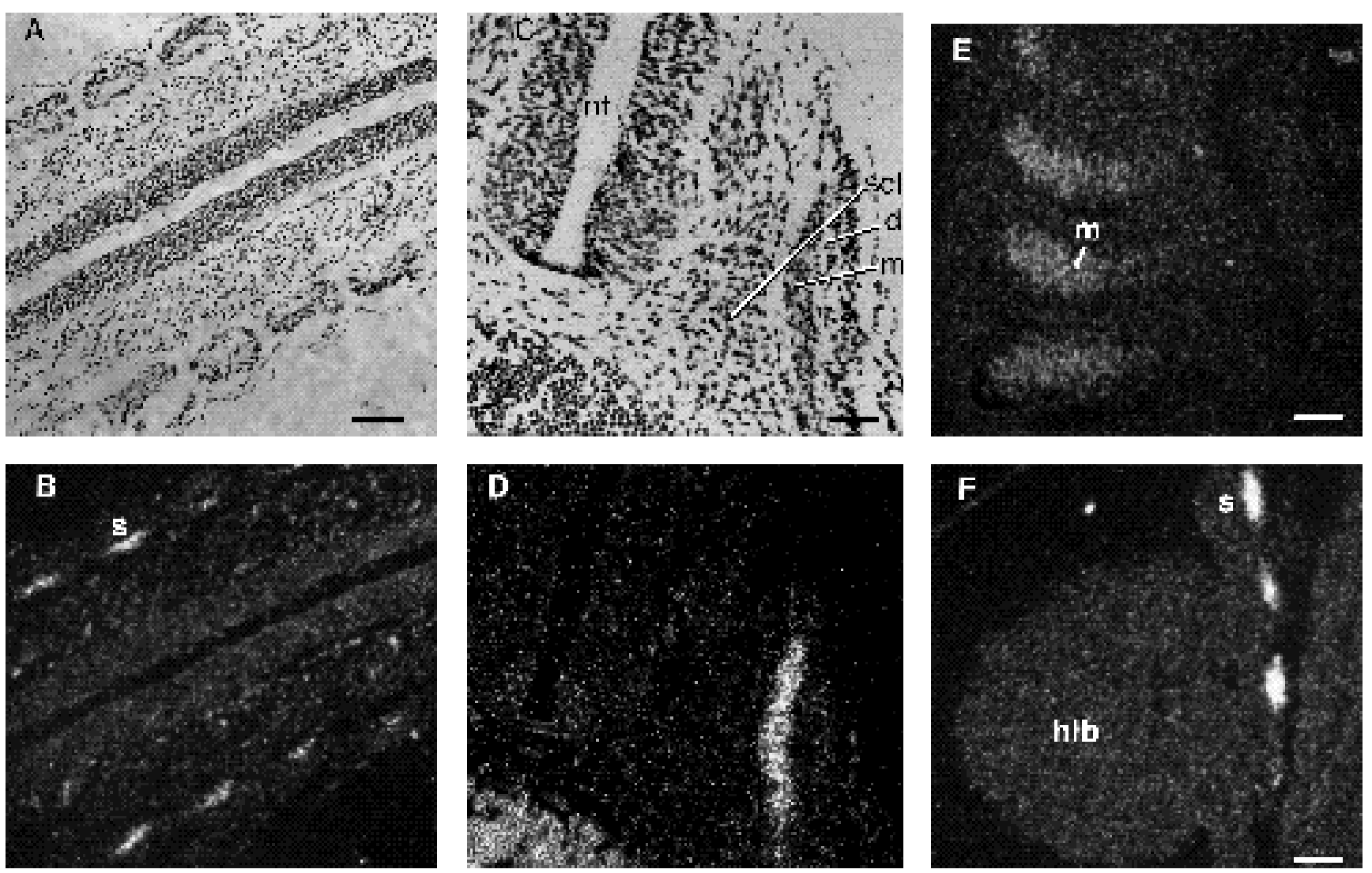

Fig. 1. Fgf6 gene transcripts are detected in the myotomal compartment of the somites at 10.5 and 11.5 d.p.c. (A,C) Bright-field photographs; (B,D,E,F) dark-field photographs of the same sections hybridized to the $F g f 6$ probe. (A,B) Somites from a 10.5 d.p.c. mouse embryo cut longitudinally; (C,D) transverse section of a 10.5 d.p.c. mouse embryo, the signal is limited to the somite, tissue refraction gives a false signal in blood cells; (E,F) sections through a 11.5 d.p.c. embryo. (E) Sagittal section showing expression in rostral myotomes, (F) transverse section showing positive somites near the hindlimb bud. At 10.5 and 11.5 d.p.c. Fgf6 expression is restricted to the myotomal compartment of the somites. Abbreviations: s, somite; nt, neural tube; scl, sclerotome; d, dermatome; m, myotome; hlb, hindlimb bud. Bars: (A,B,E,F) $100 \mu \mathrm{m}$; (C,D) $50 \mu \mathrm{m}$.

the Fgf6 probe showed a strong hybridization signal at the periphery only (Figs 2F,G, 3).

15.5 d.p.c. is the stage at which the mature pattern of muscle groups is formed, neuromuscular junctions are becoming established and secondary muscle fibres begin to appear (Ontell and Kozeka, 1984; Kieny et al., 1986). At this stage, Fgf6 transcripts were present in the muscle masses (Fig. 4), along the myotubes (Fig. 4C-F). Labelling with the $F g f 6$ probe began to decrease from 16.5 d.p.c. (data not shown).

\section{Comparison of the fetal expression of $F g f 6$ and Fgfr4}

FGFR4 could be a putative receptor for FGF6. To further investigate the relationship between $\mathrm{Fgf6}$ and $\mathrm{Fgfr} 4$ expression, parallel sections of embryos were hybridized to Fgf6 and Fgfr4 probes. Comparison of both patterns of hybridization showed that $F g f r 4$ RNAs were more widely distributed than Fgf6 (Fig. 5). Thus, some muscle masses, such as the fibres surrounding the tongue, were positive for Fgfr4 and negative for Fgf6 (Figs 5A-D, 6). In addition, the distribution of the positive cells was different for each probe. Thus, Fgfr 4 labelling was more extensive than that of Fgf6 which seemed, in contrast, highly restricted, like $\alpha$-cardiac actin, to linear arrays of cells indicative of fibres (Fig. 6). Furthermore, in a given muscle mass, Fgfr4 mRNAs were evenly distributed over the whole mass whereas Fgf6 signal was stronger at the periphery of the mass (Fig. 5E, F).

The patterns of expression of $\mathrm{Fgf6}$ and $\mathrm{Fgfr} 4$ in developing muscle are summarized in Table 1 and compared to that of other $F g f$ s, $F g f$ receptors and muscle specific genes. Fgf6 appears at the same time as Fgf4 and Fgfr4, whereas the onset of MyoDI and Fgf5 expression is one day later. Fgf6 is the only FGF, studied by in situ hybridization, found to be expressed after 14.5 d.p.c., a time where $F g f r l$ is also expressed.

\section{The terminal differentiation of $\mathbf{C 2}$ myoblasts is repressed by FGF6}

To verify that FGF6 was indeed able to regulate skeletal muscle differentiation, we treated $\mathrm{C} 2$ mouse myoblasts with recombinant FGF6 protein in conditions allowing the fusion of myoblasts into myotubes (see Materials and methods). 48-72 hours later, we looked at the number of morphologically differentiated colonies and the synthesis of muscle 

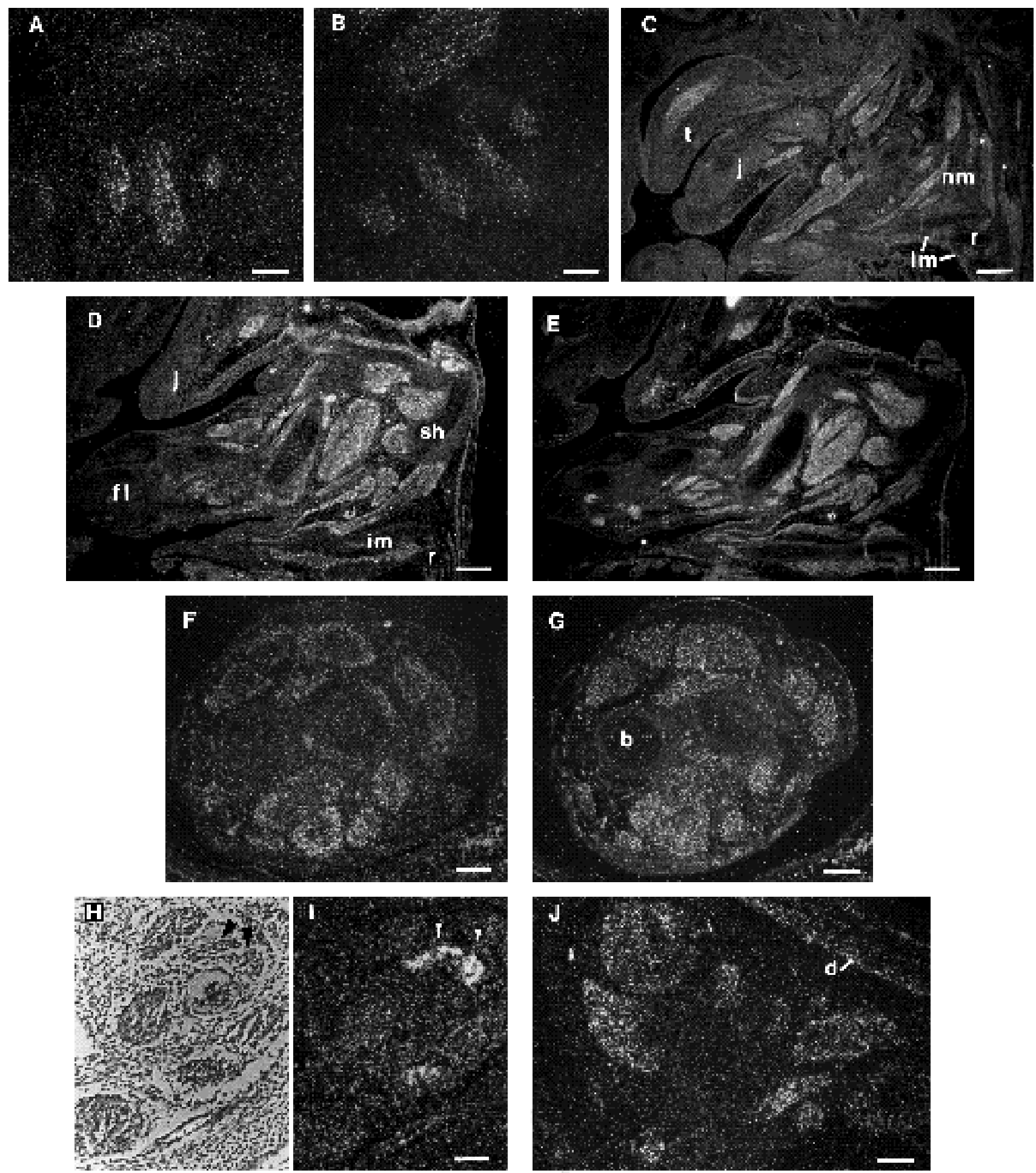

Fig. 2. Fgf6 gene expression in developing skeletal muscles. (A) Dark-field micrograph of a section through the neck region of a 12.5 d.p.c. embryo hybridized to the $F g f 6$ probe. (B) Section parallel to A hybridized to the $\alpha$-cardiac actin probe. Comparison of both sections shows that Fgf6 mRNAs are expressed in the neck muscle masses but to a lesser extent than $\alpha$-cardiac actin. (C) Sagittal section in part of the head and neck region of a 14.5 d.p.c. embryo hybridized to the $F g f 6$ probe showing expression in skeletal muscles including tongue (t), jaw (j), neck (nm), intercostal muscles (im) and rib. (r). (D) Expression of $F g f 6$ in a parasagittal section through the same embryo as in $\mathrm{C}$ and (E) expression of $\alpha$-cardiac actin in a parallel section. The Fgf6 gene is expressed in the proximal developing muscles of the forelimb (fl) and in the shoulder muscles (sh). (F) Expression of Fgf6 in the hindlimb of a 14.5 d.p.c. compared with (G) expression of $\alpha$ cardiac actin; Fgf6 expression is restricted to muscle masses; bone (b) is negative; $(\mathrm{H})$ bright-field photograph through the eye muscles at the same stage and (I) dark-field of the same section showing Fgf6 transcripts in extrinsic oculomotor muscles (arrowheads). (J) Parasagittal section through the thigh of a 13.5 d.p.c. embryo hybridized to the $F g f 6$ probe showing a positive signal in the diaphragm (d) and thigh muscles. Bars: (A, B,F,G,J) $100 \mu \mathrm{m}$; (C,D,E) $300 \mu \mathrm{m}$; (H,I) $50 \mu \mathrm{m}$. 

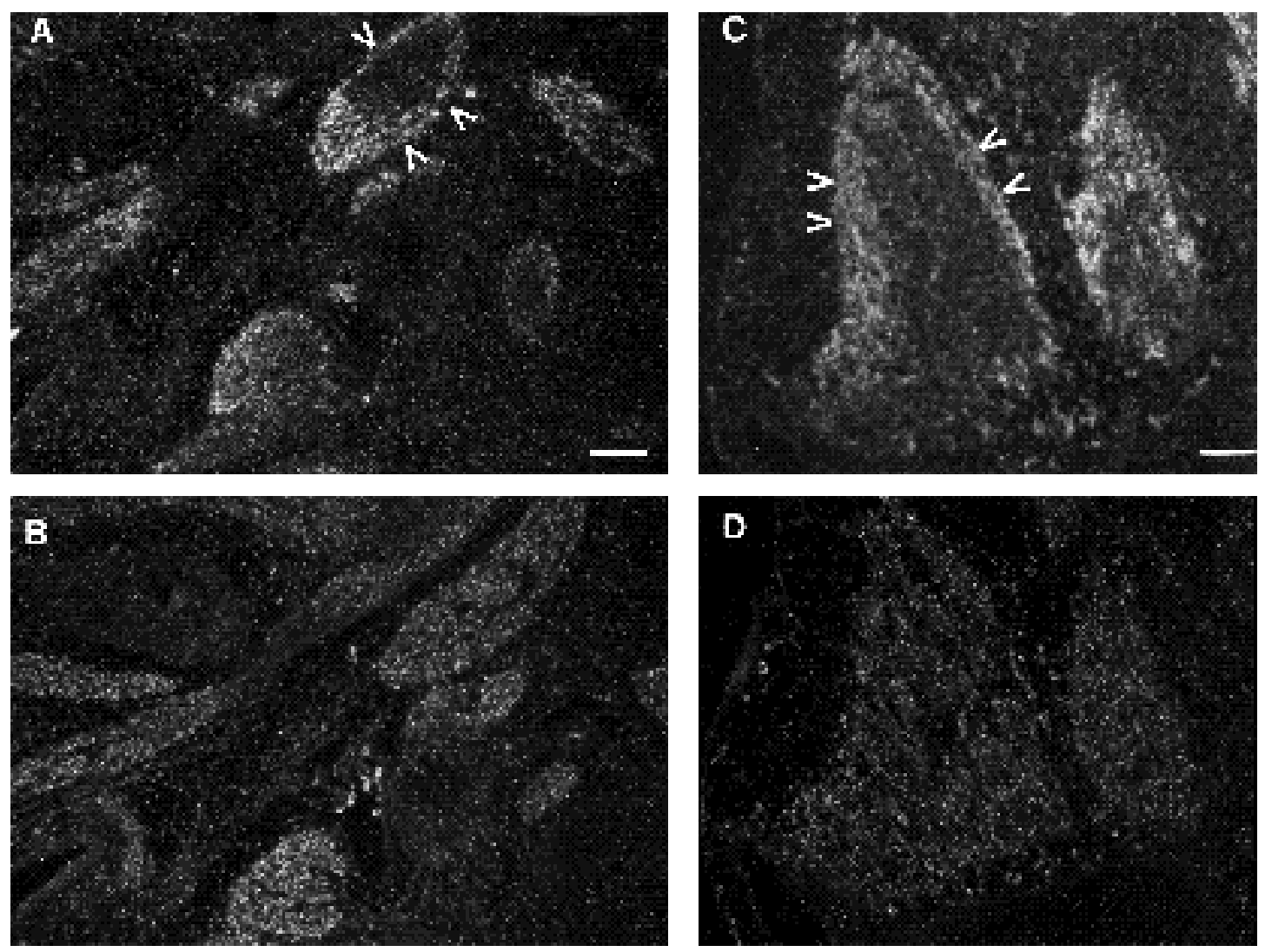

Fig. 3. Localization of Fgf6 transcripts at the periphery of the muscle masses. Dark-field views of sections through the neck (A,B) or the shoulder (C,D) of a 14.5 d.p.c. embryo hybridized to the $F g f 6$ probe (A,C), and parallel sections hybridized to the $\alpha$-cardiac actin probe (B,D). Fgf6 transcripts are not uniformly distributed over the muscle masses, the signal being more intense at the periphery. Bars, 100 $\mu \mathrm{m}$.

Table 1. Developmental accumulation of transcripts coding for myogenic regulators, FGFs and their receptors in somites, myotomes and skeletal muscles*

\begin{tabular}{|c|c|c|c|c|c|c|c|c|}
\hline Days p.c. & 8.5 & 9.5 & 10.5 & 11.5 & 12.5 & 14.5 & 15.5 & 16.5 \\
\hline$\alpha$-cardiac actin $\dagger$ & + & + & + & + & + & + & + & + \\
\hline$M y f-5 \dagger$ & + & + & + & + & + & + & - & - \\
\hline Myogenin $\dagger$ & + & + & + & + & + & + & + & + \\
\hline MyoD $1 \dagger$ & - & - & + & + & + & + & + & + \\
\hline$M y f-6 \dagger$ & - & + & + & - & - & + & + & + \\
\hline$F g f 4 \ddagger$ & - & + & + & + & + & + & - & - \\
\hline Fgf $5 \S$ & - & - & + & + & + & - & - & - \\
\hline Fgf6 & - & + & + & + & + & + & + & + \\
\hline Fgfr 1ब & - & - & - & - & - & ND & ND & + \\
\hline$F g f r 2 \mathbb{I}$ & - & - & - & - & - & - & - & - \\
\hline Fgfr $4^{* *}$ & - & + & + & + & + & + & + & + \\
\hline \multicolumn{9}{|c|}{$\begin{array}{l}\text { *Changes in mRNA levels are not indicated; spatial pattern of } \\
\text { expression of each gene is not indicated. } \\
\quad \nmid \text { Reviewed by Ott and Buckingham, 1992; myogenin protein could only } \\
\text { be detected after 10.5 d.p.c. (Cusella-De Angelis et al., 1992). } \\
\text { \$Niswander and Martin, 1992; M. Goldfarb, personal communication. } \\
\text { §Haub and Goldfarb, 1991. } \\
\text { TOOrr-Urtreger et al., 1991; Peters et al., 1992. Murine Fgfr3 expression } \\
\text { has not been reported yet. } \\
\text { **Stark et al., 1991; this study. }\end{array}$} \\
\hline
\end{tabular}

specific troponin T. Under these culture conditions, FGF6 affected the morphology of the cells: treated cultures developed a flattened, fibroblastic morphology characteristic of exponentially growing cells (not shown) and reminiscent of the influence of FGF2 on the differentiation of myoblasts in culture. FGF2 repressed the terminal differentiation of C2 myoblasts as reported previously (Lathrop et al., 1985; Clegg et al., 1987). This result is presented for comparison with the effect obtained with FGF6 (Fig. 7). Both growth factors repressed the differentiation of $\mathrm{C} 2$ cells, as defined by a reduced number of differentiated colonies (Fig. 7A), as well as a low synthesis of troponin T (Fig. 7B). FGF6 activity was lower than that of FGF2 and was increased in the presence of $0.1 \mu \mathrm{g} / \mathrm{ml}$ heparin. Similar effects of heparin upon FGF6 and various FGF activities have been reported previously (Pizette et al., 1991; Olwin and Rapraeger, 1992).

To determine whether this effect could be mediated through FGFR4, Fgfr4 expression in C2 cells was visualized by northern blot hybridization. The result indicates that Fgfr4 is indeed expressed in C2 myoblasts and downregulated in $\mathrm{C} 2$ myotubes whereas, as expected, $\alpha$-cardiac actin is upregulated during myogenic differentiation (Fig. 8).

\section{DISCUSSION}

\section{Fgf6 expression is restricted to developing skeletal muscles}

The observed tissue specificity of Fgf6 expression during 

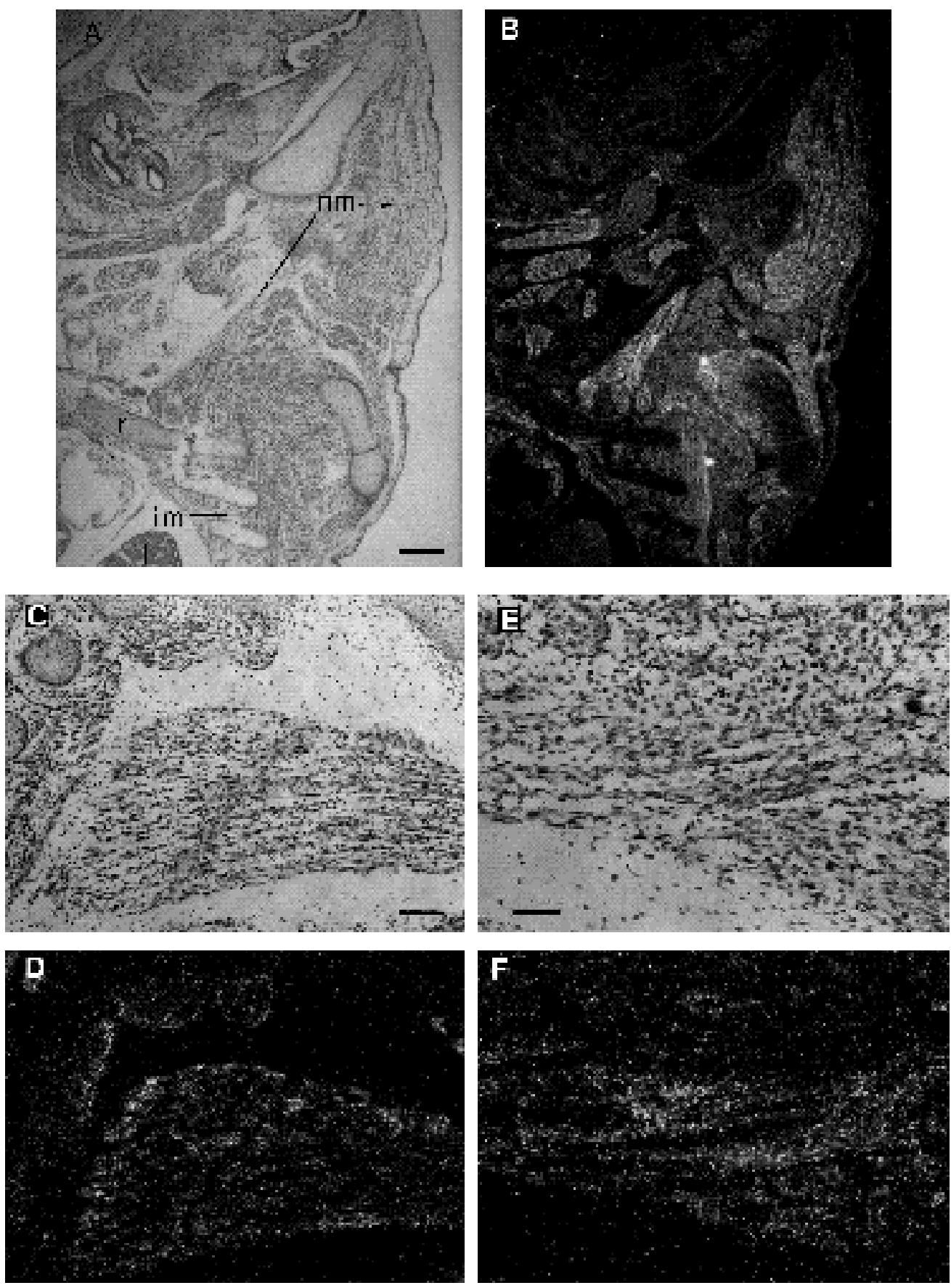

Fig. 4. Fgf6 expression in a 15.5 d.p.c. embryo.

(A,C,E) Bright-field and $(\mathrm{B}, \mathrm{D}, \mathrm{F})$ dark-field views of the sagittal sections through the neck. (C-F) High power view of neck muscles showing myotubes with arrays of grains. Bars $(\mathrm{A}, \mathrm{B})$ : $300 \mu \mathrm{m} ;(\mathrm{C}, \mathrm{D}) 100 \mu \mathrm{m} ;(\mathrm{E}, \mathrm{F})$ $50 \mu \mathrm{m}$. postimplantation embryogenesis suggests that this factor plays a role in myogenesis. Indeed, its expression is restricted to developing skeletal muscle. Non-muscle tissues, and both cardiac muscle and smooth muscles, which do not derive from somitic mesoderm, are negative. In adult tissues, Fgf6 expression was visualized by northern blot hybridization in skeletal muscle and very faintly in heart tissue (deLapeyrière et al., 1990). This discrepancy about the expression in the heart could be explained by a very low expression below the threshold of detection or by a different pattern of expression between adult and embryonic tissues. Fgf6-positive cells are distributed among the developing muscle masses whatever their embryonic origin since the extra-oculomotor muscles, which derive from the prechordal plate, are positive like other muscles derived from the dermamyotome or the myotome (Ott and Buckingham, 1992, for review). Fgf6 gene expression is first detected in the myotomes of 9.5 d.p.c. somites when transcripts coding for early isoforms of myosin begin to accumulate (Lyons et al., 1990). It continues in most but not all developing muscles, as the myotubes develop and are organized into muscle fibres. It begins to decrease from 16.5 d.p.c. The timing of detection of $F g f 6$ transcripts, and the analysis at high magnification both suggest that $F g f 6$ is expressed in muscle fibres. However, the precision of the in situ hybridization does not permit a clear distinction between tran- 

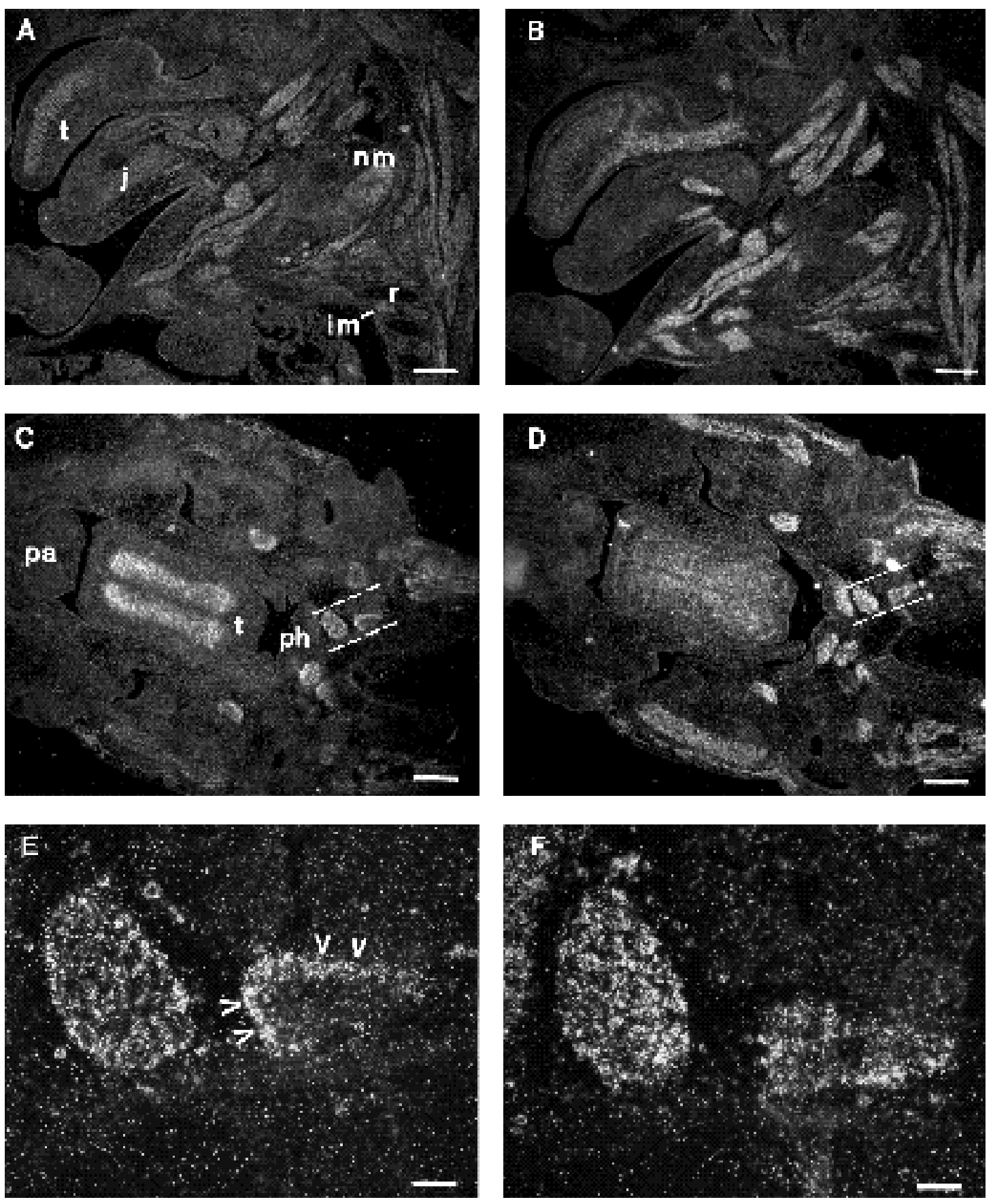

Fig. 5. Differential expression of $F g f 6$ and $F g f r 4$ in developing skeletal muscles. Dark-field views of near adjacent sections through a 14.5 d.p.c. embryo hybridized to the $F g f 6$ (A,C,E) and the Fgfr4 probes (B,D,F). (A,B) Sagittal sections of the mouth and neck regions, (C,D) transverse sections at the level of the tongue. (E,F) High power view of the boxed areas from $\mathrm{C}$ and D respectively. Note that Fgfr4 transcripts are present at higher levels than Fgf6 transcripts (exposure times are 10 days and 1 month, respectively), and that the grain distribution is different for each probe: Fgfr4 transcripts are more widespread than Fgf6 transcripts. The latter are not present in all muscle masses (C), and are more intense at their periphery (D). Abbreviations: t, tongue; j, jaw; nm, neck muscle; im, intercostal muscle; pa, palate; ph, pharynx; r, rib. Bars: (A-D) $300 \mu \mathrm{m}$; (E,F) $50 \mu \mathrm{m}$.

scripts distributed in the fibres and those in the myoblasts bordering the myotubes.

Fgf6 expression is preferentially localized at the periphery of some muscle masses. This regionalization may reflect the state of maturation of the muscle fibres and/or their future myofibre type. Another possibility is that Fgf6 expression is induced or maintained by a signal located at the periphery.

\section{FGFR4 could be one of the in vivo receptors for FGF6}

To elucidate the role of FGF6 in myogenesis, it is neces- 

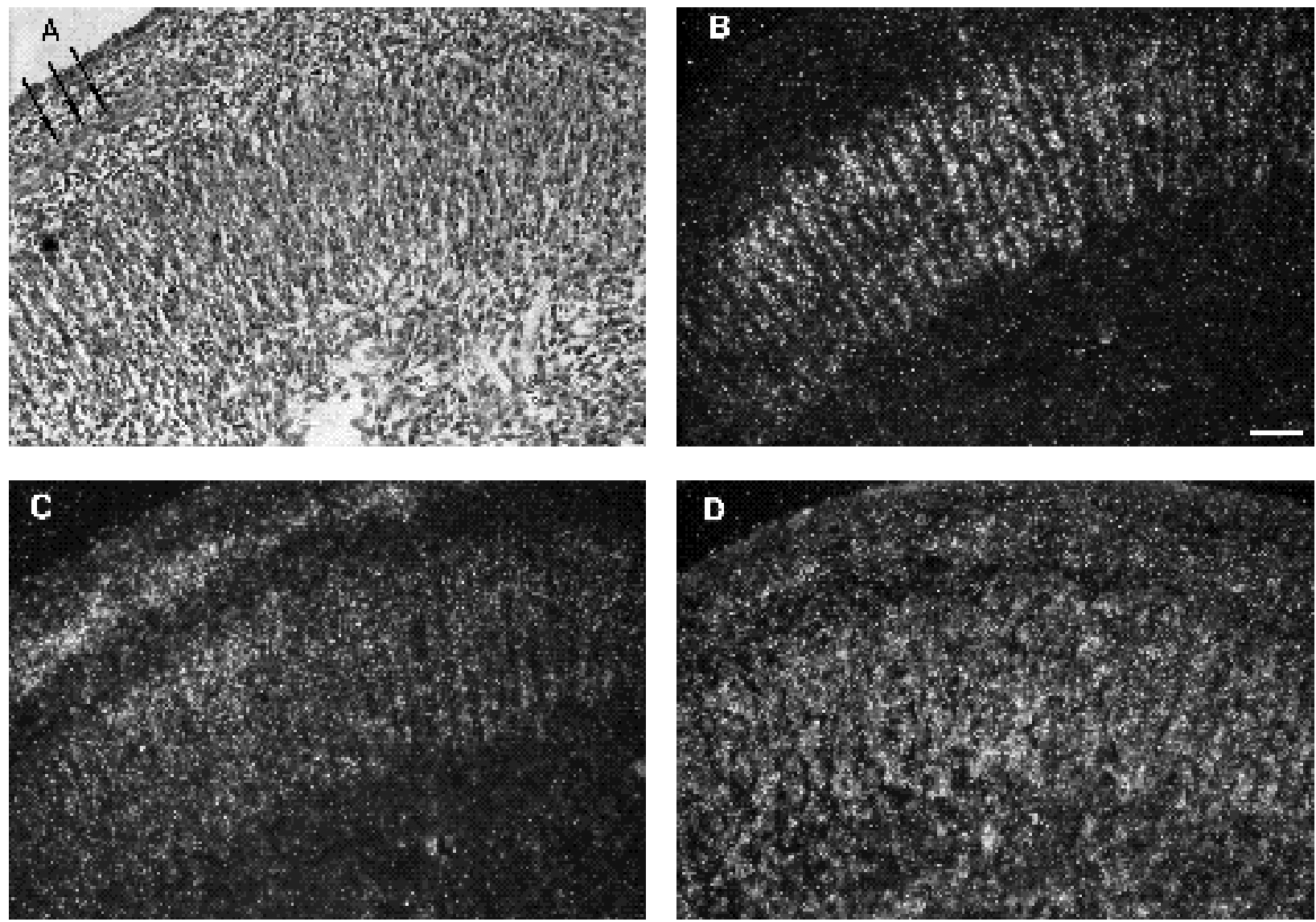

Fig. 6. Expression of the $F g f 6$ gene in the tongue. (A) Bright-field and (B-D) dark-field photographs of neighbouring sagittal sections through the tongue of a 14.5 d.p.c. embryo; (A,B) hybridization to the $F g f 6$ probe, (C) $\alpha$-cardiac actin probe and (D) $F g f r 4$ probe. $F g f 6$ transcripts are not detected in all the $\alpha$-cardiac actin-positive cells particularly those forming the superficial muscle layer. $F g f r 4$ mRNAs are widely distributed throughout the tongue, even in non $\alpha$-cardiac actin-positive cells. Arrows indicate fibres positive for the $\alpha$-cardiac actin and Fgfr4 probes, and negative for the Fgf6 probe. Bar, $50 \mu \mathrm{m}$.

sary to identify the cells that may be competent to respond to an FGF6 signal, and therefore to determine the distribution of its cognate receptor. Among the known FGF receptors (Givol and Yayon, 1992), FGFR4 seems a good candidate for being an in vivo FGF6 receptor. This assumption is based on two lines of evidence: in competition experiments, FGFR4 binds FGF6 with a high affinity (Vainikka et al., 1992); the pattern of Fgfr4 expression overlaps with that of Fgf6 (Table 1). Fgfr4 is mainly expressed in the definitive endoderm and in developing muscles (Stark et al., 1991). Indeed, we show here that Fgf6 and Fgfr4 are coexpressed in the same muscle masses. However, close examination of hybridizations with both probes suggests that both genes are not always expressed in the same cells. Fgfr4-positive cells are evenly scattered in a muscle mass, while Fgf6 transcripts are distributed in a nonhomogenous manner, with a strong signal over the peripheral developing myotubes or on linear arrays of cells. These results suggest that FGF6 may act through autocrine and paracrine mechanisms. Alternatively, another FGF could interact with FGFR4 in the regions where Fgf6 is not expressed. Independently or simultaneously, FGF6 could interact with another FGF receptor; one of them could be FGFR1, since, like FGF6, FGFR1 is expressed in the tongue and in late developing muscles (Table 1; Orr-Urtreger et al., 1991; Peters et al., 1992).

In vitro differentiation of $\mathrm{C} 2$ myoblasts into myotubes is accompanied by a downregulation of Fgfr4. Similar results have been reported about the expression of Fgfrl (Moore et al., 1991; Templeton and Hauschka, 1992).

\section{Developing skeletal muscle, a major site of FGFs expression during later embryogenesis}

The analysis of the in vivo distribution of other members of the FGF family shows that FGF1, FGF2, FGF4 and FGF5 are also expressed in developing muscle. In contrast to FGF1 and FGF2, which have been studied at the level of the protein, and in species other than the mouse (JosephSilverstein et al., 1989; Gonzalez et al., 1990; Fu et al.,1991), extensive analyses of the spatial and temporal distribution of murine $F g f 4$ and $F g f 5$ transcripts have been performed (Haub and Goldfarb, 1991; Niswander and Martin, 1992). This enables comparative profiles to be established. The patterns of expression of $\mathrm{Fgf4}$ and $\mathrm{Fgf5}$ during myogenesis are more restricted than that of $F g f 6$ : first, $F g f 4$ and $F g f 5$ transcripts are restricted to certain muscle masses (M. Goldfarb, personal communication); second, Fgf6 expression continues at later stages (after day 

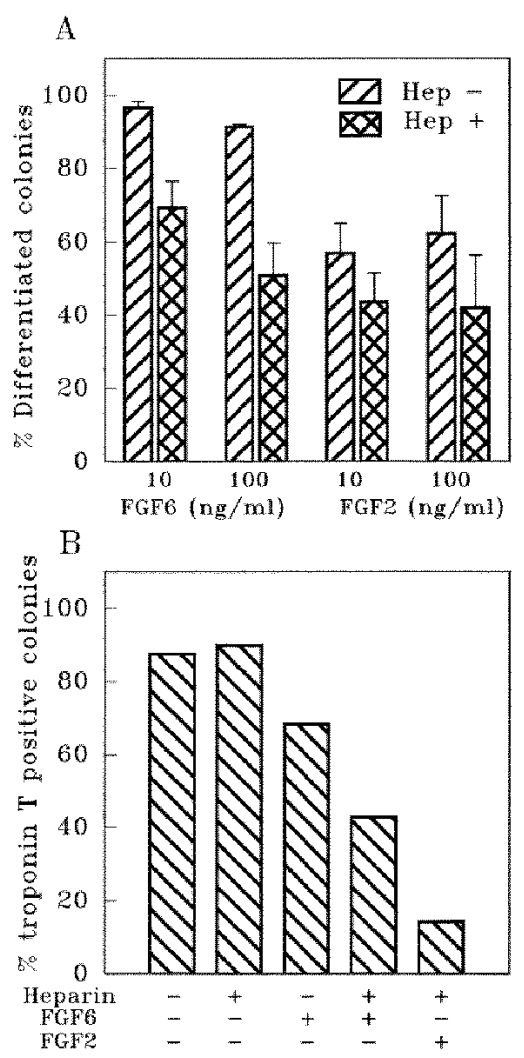

Fig. 7. FGF6 represses the terminal differentiation of $\mathrm{C} 2$ myoblasts into myotubes. C2 cells were plated at 100-200 cells/90 $\mathrm{mm}$ dishes and grown in the presence of either FGF6 or FGF2 (A: 10 or $100 \mathrm{ng} / \mathrm{ml}$; B: $100 \mathrm{ng} / \mathrm{ml})$ supplemented (Hep +) or not (Hep -) with $0.1 \mu \mathrm{g} / \mathrm{ml}$ heparin. Proteins were added every other day. After the initial period of growth, cells were shifted to a differentiation medium containing $1 \%$ FCS and $10 \mu \mathrm{g} / \mathrm{ml}$ insulin for 48 or 72 hours. (A) Colonies were ethanol-fixed, stained with Giemsa and evaluated for morphology. Results (means of three experiments and standard error) are expressed as a percentage of differentiated colonies (number of differentiated colonies in the presence of protein/number of differentiated colonies in the absence of protein). (B) Colonies were acetone/methanol-fixed and tested using a standard immunofluorescence procedure with a monoclonal antibody against troponin $\mathrm{T}$. Results are expressed as percentages of troponin-T-positive colonies.

14.5) whereas Fgf4 and Fgf5 are, at that time, down regulated.

Although several FGF genes are activated during myogenesis, their different patterns of expression suggest that they play distinct roles in the differentiation process. They may also act in synergy or be redundant for crucial steps. A possible functional redundancy of key players in myogenesis is supported by recent results (Braun et al., 1992; Rudnicki et al., 1992).

\section{What is the actual function of FGF6 in myogenesis?}

In vitro properties of the recombinant FGF6 protein are in agreement with a role of FGF6 in myogenesis. Indeed, FGF6 protein represses the terminal differentiation of $\mathrm{C} 2$ myoblasts in culture. This property is shared with other

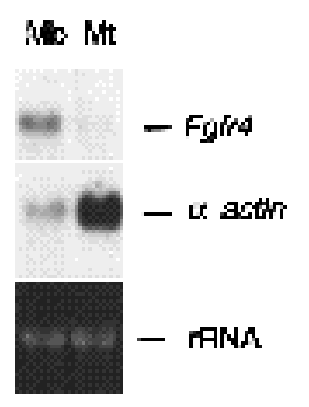

Fig. 8. Fgfr4 is expressed in $\mathrm{C} 2$ myoblasts and downregulated in myotubes. Total RNAs $(10 \mu \mathrm{g})$ were loaded in each lanes and analyzed by northern blot hybridization. A $3.6 \mathrm{~kb}$ transcript corresponding to $\mathrm{Fgfr} 4$ is observed in subconfluent myoblasts $(\mathrm{Mb})$ and decreases in myotubes $(\mathrm{Mt})$. As an indicator of the differentiation stage, a $1.6 \mathrm{~kb}$ transcript corresponding to $\alpha$-cardiac actin is faintly visible in myoblasts and increases in myotubes. The ethidium-stained ribosomal RNA gives an indication of the quantity and integrity of the loaded RNAs.

FGFs such as FGF1, FGF2, FGF4 and FGF5 (Lathrop et al., 1985; Clegg et al., 1987; Seed and Hauschka, 1988; M. Goldfarb, personal communication). It is, however, difficult to draw an exact parallel between the in vitro and in vivo activities of FGF6, since Fgf6 transcripts seem present both in myocytes and myotubes. We could assume that FGF6 is synthesized by myocytes, that it increases their proliferation, and delays their own program of differentiation by an autocrine mechanism. In myotubes, FGF6 may exert a different function. It could inhibit the terminal differentiation of a subset of myogenic cells and be required for the fusion of others. Alternatively, FGF6 produced by the myotubes could, by a paracrine effect, stimulate the proliferation of adjacent myoblasts before their fusion into developing muscles in order to maintain a self-renewal capacity in the proliferating myoblast population. This latter activity of FGF6 could be important in the growth of muscle masses, and could account for continuous expression of Fgf6 during development as well as in the skeletal muscles of the adult (deLapeyrière et al., 1990).

A family of myogenic regulatory genes has been described. Members of this family belong to the helix-loophelix (HLH) superfamily of DNA binding proteins (see Olson, 1990; Weintraub et al., 1991 and Wright, 1992 for reviews). Several lines of evidence link the FGF family to these muscle-specific transcription factors. FGF2 can repress transcription of at least two of the myogenic regulatory genes, myogenin and MyoDl (Vaidya et al., 1989; Brunetti and Goldfine, 1990). The comparison of the expression profile of Fgf6 with those of the myogenic regulatory genes (Table 1) shows that $F g f 6$ transcripts begin to accumulate in myotomes at the same time as $M y f-6$, when $M y f-5$ is already present, and one day earlier than MyoD1 and myogenin proteins accumulate (Cusella-De Angelis et al., 1992; Ott and Buckingham, 1992 and Buckingham, 1992, for reviews). The question of whether FGF6 regulates the expression of myogenic HLH proteins or whether these proteins regulate Fgf6 expression could be answered by the study of $F g f 6$ expression in mice lacking $M y f-5$ or MyoD1 (Braun et al., 1992; Rudnicki et al., 1992). Identification of both the regulatory elements and the targets of FGF6 and of other proteins of this family will provide clues to better understanding of the developmental mechanisms of myogenesis.

We would like to thank A. McMahon and M. Buckingham for 
providing probes, C. Pinset and D. Montarras for C2 cells and $\mathrm{H}$. Prats for FGF2 protein. We thank C. Mawas for enthusiastic support, our laboratory colleagues for helpful criticisms and advice, and A. Garzino for excellent animal care. We thank M. Buckingham and F. Birg for discussions and critical reading of the manuscript. We are grateful to D. Wilkinson and M. Buckingham for their advice and hospitality. We wish to thank D. Benharroch for helping in the beginning of this work. This work was supported by INSERM and grants from ARC and AFM. V. O. is the recipient of a Fellowship from the Ligue Nationale Française Contre le Cancer and S. P. is the recipient of a Fellowship from the Ministère de la Recherche et de l'Espace.

\section{REFERENCES}

Benharroch, D. and Birnbaum, D. (1990). Biology of the fibroblast growth factor gene family. Isr. J. Med. Sci. 26, 212-219.

Braun, T., Rudnicki, M. A., Arnold, H.-H. and Jaenisch, R. (1992). Targeted inactivation of the muscle regulatory gene $M y f-5$ results in abnormal rib development and perinatal death. Cell 71, 369-382.

Brunetti, A. and Golfine, I. D. (1990). Role of myogenin in myoblast differentiation and its regulation by fibroblast growth factor. J. Biol. Chem. 265, 5960-5963.

Buckingham, M. (1992). Making muscle in mammals. Trends Genet. 8, 144-148.

Clegg, C. H., Linkhart, T. A., Olwin, B. B. and Hauschka, S. D. (1987). Growth factor control of skeletal muscle differentiation: commitment to terminal differentiation occurs in $\mathrm{G} 1$ phase and is repressed by fibroblast growth factor. J. Cell Biol. 105, 949-956.

Cusella-De Angelis, M. G., Lyons, G., Sonnino, C., De Angelis, L., Vivarelli, E., Farmer, K., Wright, W. E., Molinaro, M., Bouchè, M., Buckingham, M. and Cossu, G. (1992). MyoD, Myogenin independent differentiation of primordial myoblasts in mouse somites. J. Cell. Biol. 116, 1243-1255.

deLapeyrière, O., Rosnet, O., Benharroch, D., Raybaud, F., Marchetto, S., Planche, J., Galland, F., Mattéi, M.-G., Copeland, N. G., Jenkins, N. A., Coulier, F., and Birnbaum, D. (1990). Structure, chromosome mapping and expression of the murine Fgf-6 gene. Oncogene 5, 823-831.

Fu, Y. M., Spirito, P., Yu, Z. X., Biro, S., Sasse, J., Lei, J., Ferrans, V., Epstein, S. and Casscells, W. (1991). Acidic fibroblast growth factor in the developing rat embryo. J. Cell Biol. 114, 1261-1273.

Joseph-Silverstein, J., Consigli, S. A., Lyser, K. M. and Ver Pault, C. (1989). Basic fibroblast growth factor in the chick embryo: Immunolocalization to striated muscle cells and their precursors. J. Cell Biol. 108, 2459-2466.

Givol, D. and Yayon, A. (1992). Complexity of FGF receptors: genetic basis for structural diversity and functional specificity. FASEB J. 6, 33623369 .

Goldfarb, M. (1990). The fibroblast growth factor family. Cell Growth Diff. 1, 439-445

Gonzalez, A., Buscaglia, M., Ong, M. and Baird, A. (1990). Distribution of basic fibroblast growth factor in the 18-day rat fetus: localization in the basement membranes of diverse tissues. J. Cell Biol. 110, 753-765.

Haub, O. and Goldfarb, M. (1991). Expression of the fibroblast growth factor-5 gene in the mouse embryo. Development 112, 397-406.

Hébert, J. M., Boyle, M. and Martin, G. R. (1991). mRNA localization studies suggest that murine FGF-5 plays a role in gastrulation. Development 112, 407-415.

Kieny, M., Patou, M., Chevallier, A. and Mauger. (1986). Spatial organization of the developing limb musculature in birds and mammals. Bibl. Anat. 29, 65-90.

Kimelman, D. and Kirschner, M. (1987). Synergistic induction of mesoderm by FGF and TGF-beta and the identification of an mRNA coding for FGF in the early Xenopus embryo. Cell 51, 869-877.

Lathrop, B., Olson, E. and Glaser, L. (1985). Control by fibroblast growth factor of differentiation in the $\mathrm{BC} 3 \mathrm{H} 1$ muscle cell line. J. Cell Biol. 100 1540-1547.

Lyons, G. E., Ontell, M., Cox, R., Sassoon, D. and Buckingham, M. (1990). The expression of myosin genes in developing skeletal muscle in the mouse embryo. J. Cell Biol. 111, 1465-1476.

Marics, I., Adélaïde, J., Raybaud, F., Mattéi, M.-G., Coulier, F.,
Planche, J., deLapeyrière, O. and Birnbaum, D. (1989). Characterization of the Hst-related FGF. 6 gene, a new member of the fibroblast growth factor gene family. Oncogene 4, 335-340.

Melton, D. A., Krieg, P. A., Rebagliati, M. R., Maniatis, T., Zinn, K. and Green, M. R. (1984). Efficient in vitro synthesis of biologically active RNA and RNA hybridization probes from plasmids containing a bacteriophage SP6 promoter. Nucl. Acids Res. 12, 7035-7056.

Moore, J. W., Dionne, C., Jaye, M. and Swain, J. L. (1991). The mRNAs encoding acidic FGF, basic FGF and FGF receptor are coordinately downregulated during myogenic differentiation. Development 111, 741748.

Niswander, L. and Martin G. R. (1992). Fgf-4 expression during gastrulation, myogenesis, limb and tooth development in the mouse. Development 114, 755-768.

Ollendorff, V., Rosnet, O., Marics, I., Birnbaum, D. and deLapeyrière, O. (1992). Isolation and sequence of the murine Fgf6 cDNA. Biochimie 74, 1035-1038.

Olson, E. N. (1990). MyoD family: a paradigm for development? Genes Dev. 4, 1454-1461.

Olwin, B. B. and Rapraeger, A. (1992). Repression of myogenic differentiation by aFGF, bFGF, and K-FGF is dependent on cellular heparan sulfate. J. Cell Biol. 118, 631-639.

Ontell, M. and Kozeka, K. (1984). The organogenesis of murine striated muscle: a cytoarchitectural study. Am. J. Anat. 171, 133-148.

Orr-Urtreger, A., Givol, D., Yayon, A., Yarden, Y. and Lonai, P. (1991). Developmental expression of two murine fibroblast growth factor receptors, $f g$ and bek. Development 113, 1419-1434.

Ott, M. O. and Buckingham, M. (1992). Expression of myogenic factors in somites and limb buds during mouse embryogenesis. In Formation and Differentiation of Early Embryonic Mesoderm. NATO ASI Series: Life Science, Vol. 231 (ed. R. Bellairs et al.), pp 211-225. New-York: Plenum Press.

Peters, K. G., Werner, S., Chen, G. and Williams, L. T. (1992). Two FGF receptor genes are differentially expressed in epithelial and mesenchymal tissues during limb formation and organogenesis in the mouse. Development 114, 233-243.

Pinset, C., Montarras, D., Chenevert, J., Minty, A., Barton, P., Laurent, C. and Gros, F. (1988). Control of myogenesis in the mouse myogenic $\mathrm{C} 2$ cell line by medium composition and by insulin: characterization of permissive and inducible C2 myoblasts. Differentiation 38, 28-34.

Pizette, S., Batoz, M., Prats, H., Birnbaum D. and Coulier, F. (1991). Production and functional characterization of human recombinant FGF-6 protein. Cell Growth Differ. 2, 561-566.

Rudnicki, M. A., Braun, T., Hinuma, S. and Jaenisch, R. (1992). Inactivation of $M y o D$ in mice leads to up-regulation of the myogenic HLH gene $M y f-5$ and results in apparently normal muscle development. Cell 71, 383-390.

Sassoon, D. A., Garner, I. and Buckingham, M. (1988). Transcripts of $\alpha$ cardiac and $\alpha$-skeletal actins are early markers for myogenesis in the mouse embryo. Development 124, 40-49.

Seed, J. and Hauschka, S. D. (1988). Clonal analysis of vertebrate myogenesis. VII. Fibroblast growth factor (FGF)-dependent and FGFindependent muscle colony types during chick wing development. Dev. Biol. 128, 40-49.

Slack, J., Darlington, B., Heath, J. and Godsave, S. (1987). Mesoderm induction in early Xenopus embryos by heparin-binding growth factors. Nature 326, 197-200.

Stark, K. L., McMahon, J. A. and McMahon, A. P. (1991). FGFR-4, a new member of the fibroblast growth factor receptor family, expressed in the definitive endoderm and skeletal muscle lineages of the mouse. Development 113, 641-651.

Stewart, W. and Walker, C. (1989). Comparison of nylon membranes. Meth. Mol. Cell. Biol. 2, 73-76.

Templeton, T. J. and Hauschka, S. D. (1992). FGF-mediated aspects of skeletal muscle growth and differentiation are controlled by a high affinity receptor, FGFR1.Dev. Biol. 154, 169-181.

Vaidya, T. B., Rhodes, S. J., Taparowsky, E. J. and Konieczny, S. F. (1989). Fibroblast growth factor and transforming growth factor $\beta$ repress transcription of the myogenic regulatory gene Myod1. Mol. Cell Biol. 9, 3576-3579.

Vainikka, S., Partanen, J., Bellosta, P., Coulier, F., Birnbaum, D., Basilico, C., Jaye, M. and Alitalo, K. (1992). Fibroblast growth factor receptor-4 shows novel features in genomic structure, ligand binding and signal transduction. EMBO J. 11, 4273-4280. 
Weintraub, H., Davis, R., Tapscott, S., Thayer, M., Krause, M., Benezra, R., Blackwell, T., Turner, D., Rupp, R., Hollenberg, S., Zhuang, Y. and Lassar, A. (1991). The MyoD gene family: nodal point during specification of the muscle cell lineage. Science 251, 761-766.

Wilkinson, D. G., Bailes, J. A., Champion, J. E. and McMahon, A. P. (1987). A molecular analysis of mouse development from 8 to 10 days post coitum detects changes only in embryonic globin expression. Development 99, 493-500.

Wilkinson, D. G., Peters, G., Dickson, C. and McMahon, A. P. (1988). Expression of the FGF-related proto-oncogene int-2 during gastrulation and neurulation in the mouse. EMBO J.7, 691-695.
Wilkinson, D. G., Bhatt, S. and McMahon A. P. (1989). Expression pattern of the FGF-related proto-oncogene int-2 suggests multiple roles in fetal development. Development 105, 131-136.

Wright, W. (1992). Muscle bHLH proteins and the regulation of myogenesis. Curr. Opin. Genet. Dev. 2, 243-248.

Yamaguchi, T. P., Conlon, R. A. and Rossant, J. (1992). Expression of the fibroblast growth factor receptor FGFR-1/flg during gastrulation and segmentation in the mouse embryo. Dev. Biol. 152, 75-88.

(Accepted 1 March 1993) 